Paper published in the Journal of Public Finance and Public Choice 23(3): 183-195 (2004).

\title{
Economic Integration, Legitimacy \\ and European Union Enlargement
}

\author{
Andreas P. Kyriacou \\ Departament d'Economia \\ Facultat de Ciències Econòmiques i Empresarials \\ Universitat de Girona \\ Campus de Montilivi \\ 17071 Girona, Spain \\ Tel: + (34) 972418716 \\ Fax: + (34) 972418032 \\ E-mail: andreas.kyriacou@udg.es
}


Paper published in the Journal of Public Finance and Public Choice 23(3): 183-195 (2004).

\begin{abstract}
The enlargement of the European Union generates socio-economic costs and benefits for the citizens of new members and as such it is bound to affect their perceived legitimacy of the whole enterprise. The legitimacy of EU accession is likely to be enhanced by the inclusion of compensatory transfers and transition periods in the terms of accession, by the perception that EU membership represents the most favorable terms of exchange available and by the linking of accession to a sustained period of economic growth, a favorable movement in prices, improving relative incomes and the consolidation of a level playing field across new members.
\end{abstract}

Key words and JEL codes: economic integration, legitimacy, enlargement, transition economies (JEL Classification: D72, F02, P26) 
Paper published in the Journal of Public Finance and Public Choice 23(3): 183-195 (2004).

\author{
Economic Integration, Legitimacy \\ and European Union Enlargement
}

\title{
1. - Introduction
}

The economic effect of the process of integration of new members to the European Union (EU) is the subject of an ongoing debate among scholars. In the context of the latest enlargement there is a general consensus that their accession to the EU is welfare improving due to the improved resource allocation brought about by a greater competitive market as well as an increase in foreign direct investment brought about by a fall in the risk premium in candidate countries [BALDWIN ET AL, 1997; GRABBE - Hughes, 1998]. Further economic gains may emerge due to the greater credibility afforded to free market economic reforms by EU accession [PIAZOLO, 1999]. This said, the gains are likely to be unevenly distributed both among the current member states as well as among the candidate countries [Baldwin et AL, 1997; Commissariat GÉnÉRAl DU Plan, 1999]. More importantly perhaps the enlargement of the Union is likely to generate socio-economic costs across future members. There are doubts in the East about the capacity of industry and agriculture to compete as well as the cost of adapting to the acquis, especially in the field of labor and environment [FAINI - PORTES, 1995; NEVEN, D, 1995; FIDRMUC, J, 1999; IMF, 2000].

Rather than enter the debate as to the magnitude of the economic effects of enlargement, I focus here on the question of how the economic costs and benefits of enlargement can affect the legitimacy of the EU as perceived by the citizens of new member states and I will do so - by way of illustration - in the context of the latest 
enlargement. In a very general sense, one would expect legitimacy to be undermined in the eyes of economic agents to the extent that they perceive more costs than benefits for themselves from enlargement. However, a reading of the institutional economics literature on the subject together with work from sociology and political science which deals with the relationship between economic integration and legitimacy points to a more complex relationship.

2. - The Importance of Voluntary Agreement

Any institution or agreement which is not adopted voluntarily, or conversely, which is coercively imposed, is likely to be perceived as illegitimate. This concept of legitimacy is in line with the Lockean vision which considers illegitimate any non-consensual crossing of "natural boundaries" to individual rights which are assumed to be definitive and well understood [BUCHANAN, 1977]. It is further consistent with the Weberian notion of "rational-legal" legitimacy whereby authority is obeyed because of popular acceptance of the appropriateness of the system of rules under which it has won office [WEBER, 1946]. The possible existence of a direct relationship between voluntariness and legitimacy alerts us to the utility of putting the terms of accession to referendums across future member states.

Voluntariness may be inversely related to the degree of certainty faced by individuals over their own specific roles or interests once the relevant institution or agreement has been adopted. To the extent that the individual cannot identify a specific cost 
Paper published in the Journal of Public Finance and Public Choice 23(3): 183-195 (2004).

which may be imposed on him/her under the new institutional context he is more likely to voluntarily accept this context, compared to a situation where such a cost is expected. Thus, the smaller this degree of certainty or, in other words, the thicker the "veil of uncertainty", the easier it may be to attain unanimous and voluntary agreement [BUCHANAN - TULLOCK, 1962]. Uncertainty may have been low among those Eastern European citizens who may reasonably have expected to lose out from membership (unemployed, pensioners, farmers) as well those who expected to benefit (younger and better educated urbanites).

Even in the absence of uncertainty about the relative positions of parties under different terms of co-operation, individuals may voluntarily enter into an agreement insofar as they all possess viable alternatives to the contract toward which they are negotiating [LOWENBERG - YU, 1992]. In this situation, no party would be able to coerce another to accept terms of co-operation which are less favorable than the best terms which may be obtained by striking cooperative agreements with others. Arguably, the countries of Eastern Europe did not enjoy an exit option when negotiating the terms of accession while the EU did so. In other words, the EU enjoyed a certain degree of monopoly power when negotiating with these countries. Thus, it is possible that the citizens of these countries perceived some degree of coercion in the context of the pre-accession negotiations. This would necessarily reduce the voluntariness with which they may have adopted the final terms and thus ultimately be inimical to their legitimacy.

Even without uncertainty over future positions, the possibility of a package deal may lead to agreement [MUELLER, 1991]. Voluntariness may be fomented through the adoption of a "package deal" of compromises, side payments, compensations, bribes, exchanges and trade-offs, which aim to offset the predictable adverse distributional 
properties of the proposed changes [BRENNAN - BUCHANAN, 1985]. Compensatory transfers have been instrumental in achieving the acceptance of both the Single European Act and the European Monetary Union by poorer member states in the past, given the likely negative distributional effects of such deeper economic integration [BALDWIN ET AL, 1997]. They are similarly important for overcoming the resistance of anti-European interest groups in Eastern Europe and more generally, for encouraging public support for accession in these countries [Bofinger, 1995; GRABBE - Hughes, 1998]. The adverse distribution effects of accession could also have been mitigated by the agreed-upon adoption of transition periods for the application of EU laws in sensitive areas (state aids, social and environmental regulations) so as to give economic agents time to adjust to the new rules of the game.

\section{3. - The Terms of Exchange}

Douglass North argues that the terms of exchange are crucial for evaluating the perceived legitimacy of a system (e.g. capitalism) or agreement (e.g. terms of accession into the EU) and suggests four "alterations in relative prices" that may negatively affect a person's perceptions [NORTH, 1981].

The perceived legitimacy of a system may be reduced if it alters property rights such that it denies individuals access to resources which they had come to accept as customary or just. This idea is arguably relevant for the process of privatization of state assets across the former communist countries. An interesting question which emerges here 
Paper published in the Journal of Public Finance and Public Choice 23(3): 183-195 (2004).

is the extent to which public opinion considers this process to have been carried out in a fair way. To the extent that it has not been then it arguably means that the resulting change in the distribution of property rights may not necessarily be considered fair and so the perceived legitimacy of the new system may be compromised [PEJOVICH, 1996]. Importantly, to the extent moreover that such processes are linked to the transition to EU accession [KOLANKIEWICZ, 1993; FOWLER, 2001] then they may also negatively affect the perceptions of eventual EU membership.

Perceived legitimacy may fall due to a decline in the terms of exchange in a factor or product market away from what had come to be regarded as a just exchange ratio or a decline in the relative income position of a particular group in the labor force. While the latter case is self-evident, the former is related to the process of price liberalization across Eastern Europe and the subsequent effects on economic agents such as, workers, consumers and entrepreneurs. Insofar as liberalization leads to a decline in real wages, an increase in retail prices and an increase in the cost of investment is likely to generate a negative effect on the perceived legitimacy of the new system while an increase in real wages, a fall in prices and a fall in the cost of investment is likely to have the opposite effect. To the extent that EU accession is associated with the evolution of these variables (for example, a fall in inflation and interest rates in the context of European Monetary Union or a rise in food prices in the context of the Common Agricultural Policy) then these perceptions of legitimacy may extend to the EU itself.

The perceived legitimacy of a system may depend on a reduction in information costs that results in individuals perceiving that different and more favorable terms of exchange may prevail elsewhere. One can make several points in relation to this. The first is the idea 
Paper published in the Journal of Public Finance and Public Choice 23(3): 183-195 (2004).

that compared to economic integration in the context of the COMECON, reintegration into the West was probably seen as much more attractive leading to the perceived illegitimacy of the former system and ultimately its demise. Moreover, one must qualify the previous argument that to the extent that the candidates do not have a viable exit option at the time of negotiating the terms of accession then this is likely to reduce the legitimacy of accession. The unavailability of a viable exit option may be due to the fact that equal or more favorable terms of exchange do not exist elsewhere. To the extent that the EU membership is perceived by Eastern Europeans to represent the most favorable terms of exchange available then this is likely to enhance the legitimacy of accession.

\section{4. - The Persistent Influence of Informal Rules: Path Dependence}

The perceived legitimacy of formal rules may be affected by the continuing influence of informal ones or in other words because of the emergence of path dependence. Thus, "Although a wholesale change in the formal rules may take place, at the same time there will be many informal constraints that have a great survival tenacity because they still resolve basic exchange problems among the participants, be they social, political, or economic." [NORTH, 1990, p. 91]. These informal norms include routines, customs, traditions and conventions which have gradually evolved as extensions of previous formal rules. The legitimacy of the new formal rules in the post-revolutionary period may initially be small thereby increasing the cost of maintaining the post-revolutionary status quo but legitimacy increases as informal norms gradually adjust to the new formal rules and so the costs of maintaining the new order fall through time. 
Paper published in the Journal of Public Finance and Public Choice 23(3): 183-195 (2004).

The perceived legitimacy of the institutional context defined by the EU's Single Market among the economic agents of Eastern Europe will, to some extent, depend on the persistence of such informal rules. Thus, for example, to the extent that there is a tradition of equality before efficiency, this would mitigate the perceived legitimacy of the new context. That such a tradition exists is certainly suggested by Janos Kornai who writing on Hungary in 1990 states that,

"At each stage of his life, starting with the child entering kindergarden and ending with the old person retiring to a home for the aged, the citizen of a socialist country was told that not business, but only work (more specifically, work done in the framework of an enterprise or organization in the public sector) was the single legitimate source of income. He was taught that some inequality was tolerable or perhaps even useful for the sake of providing material incentives to people, but that there should not be "too much" of it ... Right now, in the beginning of a new era, many people in various political groups, even within anticommunist movements, are still under the spell of their former indoctrination in extreme egalitarian values. They regard profit or high income as the result of unethical practices, and speculation and profiteering as sure signs of unacceptable greed. [KORNAI, 1990, p. 21].

Similarly, Pejovich [1996] has argued that Eastern European citizens perceive profitseeking in a negative light and social interactions in terms of a redistributive game. Rather 
Paper published in the Journal of Public Finance and Public Choice 23(3): 183-195 (2004).

than perceiving capitalism as a way of life based on individual liberty, self-interest, selfdetermination, self responsibility, free-market competition and a work ethic, people's perceptions of capitalism during socialist rule are of a system which can generates bountiful supplies of good and income. Survey evidence presented by Duch [1993] suggests that while an overwhelming majority of the Soviet mass public recognizes the importance of the link between incentives and economic performance, a considerably smaller percentage of the public is willing to accept the inequalities that are inevitable by-products of free markets. He finds virtually no support for a reduction in the social guarantees provided by the state. Based on these results, the author concludes that,

"[to] the extent that public opinion matters in this transition process, the free-market model for the former Soviet Union will more likely resemble that of the social democracies of Western Europe, which tend to champion egalitarianism, rather than the more laissez-faire model found, for example, in the United States." [DuCH, 1993, p. 603].

The strength of path dependence is likely to vary across Eastern Europe given the differences in their cultural heritage. In those countries where the heritage of informal norms was not completely unrelated to the changes in the formal ones (eg. Czech Republic), the adoption of these rules was relatively harmonious [NORTH, 2000]. Not so in countries, like Russia where that heritage was completely out of phase. Apart from taking into account these different starting points one must also consider that the strength of these traditions more than a decade after the fall of the iron curtain is likely to be reduced. 
Paper published in the Journal of Public Finance and Public Choice 23(3): 183-195 (2004).

Notwithstanding these qualifications, the extent to which that an egalitarian bias persists across Eastern Europe this will work against the perceived legitimacy of that market competition defined by the EU's Single Market.

5. - Performance-based Legitimacy

Lipset [1959] argues that a political system may gain legitimacy to the extent that it performs well over a number of generations - performance mainly measured in terms of economic development. Thus, while the postwar democratic regimes of formerly fascist states, like post WWII Germany or Japan where "imposed" by the winners and as a result lacked legitimacy at the outset, they earned their legitimacy through sustained economic growth over four decades [LIPSET, 1994]. Similarly, the long-term economic growth which followed the Civil War contributed to the legitimacy of the American constitutional regime. In this vein, many commentators have argued that most of the legitimacy enjoyed by nondemocratic regimes such as that of Suharto in Indonesia or today's Chinese government is based on strong economic growth.

In the context of the EU Obradovic [1996] argues that the Union gains it legitimacy through the appeal to the economic welfare it may provide. This is linked to the neofunctionalist theory of European integration such that the expected benefits which may come from increased economic integration drive support and, in a sense, legitimize such integration. Thus, the crisis of support for the EC in the 1970s was due to the economic crisis and that posterior enthusiasm was due to the economic up-turn [HANDLEY, 1981]. 
Paper published in the Journal of Public Finance and Public Choice 23(3): 183-195 (2004).

The idea that the legitimacy of an institutional framework depends on the economic welfare it provides, points to the importance of sustained economic growth across Europe for the success of enlargement and the exposure of such integration projects to a prolonged period of economic downturn. Although some of the economic benefits of integration are already being enjoyed by Eastern Europe through the Europe Agreements, the "wealth effect" is yet to be fully realized given the fact that the full "dynamic benefits" are pending and so are credibility benefits. On the other hand, an unfavorable global economic conjuncture may dampen these effects.

The above authors largely define the performance of a regime in terms of the absolute growth it generates ${ }^{1}$. Another way of measuring performance which may be relevant in the context of enlargement is the capacity of the new regime to reduce the emergence of distortions to fair competition by private and public agents. One way that it may do so is by "tying the hands" of national politicians thereby limiting their capacity to respond to rent-seeking groups [MORAVCSIK, 1993; BOFINGER, 1995]. Insofar as EU membership has been perceived in these terms than it increases its legitimacy. Indeed this seems to have been the perception since,

"Oddly, the new applicants also often cite European regulation (which some existing members regard as a curse) as one of the attractions of EU membership. Even if they consider parts of the acquis communautaire silly or inappropriate for them, many Central and Eastern Europeans like the idea of rules imposed from

\footnotetext{
${ }^{1}$ Lipset [1994] also considers the performance of the political regime by way of its capacity to guard minority rights (ethnic-linguistic-religious rights).
} 
Paper published in the Journal of Public Finance and Public Choice 23(3): 183-195 (2004).

Brussels to force the new members to maintain open government and a competitive business environment. They fear that without the EU to keep order, their relatively new political and economic arrangements could still be vulnerable to crony capitalism of the Russian sort.’[THE ECONOMIST, May 2001, p. 10].

Finally, while a direct relationship may indeed exist between legitimacy and the growth in the absolute level of income, legitimacy may also be related to relative income. I have already said that legitimacy may be negatively affected by a decline in the relative income position of a particular group in the labor force. According to Inotai [2000], the majority of losers due to the transition process in Eastern Europe are relative rather than absolute losers. The importance of relative income has been discussed by Hirschman [1973] in the context of the tolerance of citizens of developing countries of economic reforms. He suggests that in the early stages of economic development when inequalities in the distribution of income may increase sharply, society's tolerance of such disparities may be large and this facilitates economic reforms. But this tolerance is extended in the expectation that disparities will narrow again (this he labels, the tunnel effect) and if this does not happen this is likely to lead to disenchantment and, probably, a rejection of reforms. The tunnel effect operates because the advances of others supply information about a more benign external environment. As long as the tunnel effect lasts everybody feels better off, both those who have become richer and those who have not ${ }^{2}$.

\footnotetext{
${ }^{2}$ The basic idea is that changes in the income of B lead to changes in A's welfare not only because A's relative position on the income scale has changed but also because changes in B's fortunes will affect A's prediction of his own future income.
} 
Paper published in the Journal of Public Finance and Public Choice 23(3): 183-195 (2004).

Arguably, something like the tunnel effect may have been experienced across Eastern Europe after the fall of the iron curtain giving margin to economic reforms in the face of growing economic inequalities. To the extent that EU accession can renew this effect then it may help consolidate the process of economic transition in the candidate countries. Hirschman [1973] points to several conditions which may determine the duration of the tunnel effect, one of which may be of interest here. According to this author, the emergence of the tunnel effect is more likely to the extent that people believe that chance (good or bad luck) or merit rather than nepotism, favoritism or similar unfair practices plays a big part in success. The latter perception is more likely the more the economy becomes more centralized, oligopolized and bureaucratized. To the extent that EU accession can reduce the perceived likelihood of this then it may increase the duration of the tunnel effect. The previous quote is suggestive of this.

6. - The "Return to Europe"

Political elites across Eastern Europe have employed the "return to Europe" argument in order to support their membership aspirations [SZCZERBIAK, 2001]. The idea of "return to Europe" has been put in the theoretical context of sociological institutionalism which "posits that the goals and procedures of international organizations are more strongly determined by the standards of legitimacy and appropriateness of the international community to which they belong than the utilitarian demand for efficient problem solving." [SCHIMMELFENNIG, 2001, p.58]. In the context of enlargement, this standard of legitimacy is the ideology of a pan-European community of liberal-democratic states and as a result 
Paper published in the Journal of Public Finance and Public Choice 23(3): 183-195 (2004).

Eastern Europeans have based their membership bid on a common heritage of these constitutive values - the "return to Europe" argument - making it difficult for current members to oppose enlargement.

The desire to "return to Europe" therefore, can legitimize the accession aspirations of prospective members vis-à-vis current member states. But the same argument together with the associated expectation that membership can help consolidate nascent democratic regimes, has been identified as generating an extraordinary readiness on the part of Eastern European societies to endure the upheaval of economic transformation and align their political and legal systems to the requirements of joining the EU [AMATO - BATT, 1999]. Similarly, the political motive of the consolidation of fragile democracies has arguably acted as a legitimizing factor for important economic and modernizing reforms undertaken by Greece, Spain and Portugal after their accession to the Union [TsOUKALIS, 2000]. Those member states which joined the EU for primarily political reasons such as the need to affirm their independence (Ireland, Luxembourg and Belgium) or overcoming historical conflicts (Germany, France and Italy) or the desire to consolidate their fragile democracies (Greece, Spain and Portugal), have experienced less skepticism than those which joined for more economic reasons (e.g., UK, Denmark and Sweden) [GRABBE-HuGHES, 1998].

At the heart of this argument is the idea that political motivations may have a stronger legitimizing influence than economic ones (represented by the performance-based legitimacy discussed above). Of course, one of the problems with this argument as a legitimizing device is that it may be weakened once prospective members eventually enter the Union or, in other words, "return to Europe" and as their democratic regimes are 
consolidated. This is especially so as the costs and concessions made to obtain membership emerge [SZCZERBIAK, 2001].

\section{7. - A Common European Identity}

The "return to Europe" argument and, in particular, the idea of a founding EU-wide myth of a liberal, antifascist and anticommunist ideology motivated by the post WWII experience, points to a sixth source of legitimacy which may sustain the enlarged EU in the face of socio-economic costs due to deeper economic integration namely, a common European identity based on shared myths, values and symbols.

Wallace [1993] describes the emergence and worsening of the EU's democratic deficit as basically the result of an asymmetry between the deepening of economic and policy integration on the one hand and the marginal adoption of democratic reforms on the other. Legitimacy, according to this author has been traditionally sought either indirectly via national parliaments or through the delivering of substantive material rewards to citizens. To the extent that legitimacy could spring from a shared European identity this could mitigate that disaffection which may emerge when performance worsens ${ }^{3}$.

\footnotetext{
${ }^{3}$ See also, Laffan [1996]. Inherent to this argument is the idea that performance-based legitimacy is devoid of mythological content. However, the functionalist project which I have previously identified with performance based legitimacy, draws on "the myth of modernity and the structures of rationalization with which it is bound up" [HANSEN - WiLLIAMS, 1999, p. 244].
} 
Obradovic [1996] similarly argues that sustained legitimacy must be based on something more than utilitarian motives or performance-based sources, for example, a shared commitment to some form of collective identity. Insofar, as this author argues, a shared identity can maintain social solidarity, then a shared European identity may facilitate EU-wide redistribution and thus soften the socio-economic costs of deeper economic integration. This said, Obradovic recognizes that there is no historically developed feeling of shared myths/values in the EU through which an EU polity can be legitimized and, moreover, argues that there is no "mythomoteur" to bring this about ${ }^{4}$. Notwithstanding this, insofar as a shared European identity can emerge over time this would legitimize deepening economic integration in an ever wider Europe.

\section{8. - Conclusions}

This article has discussed several factors which may affect the perceived legitimacy of the further economic integration inherent to an ever wider EU. The discussion has been placed in the context of the latest EU enlargement and I will conclude here by summarizing and generalizing the main implications since it is arguably applicable to both past and future enlargements.

The institution of compensatory transfers towards the new member states as well as transition periods for the application of EU rules in areas sensitive to new members would

\footnotetext{
${ }^{4}$ For a similar view see, Smith [1992]. For a more optimistic line see, Howe [1995], Hansen and Williams [1999] and Schimmelfennig [2001].
} 
Paper published in the Journal of Public Finance and Public Choice 23(3): 183-195 (2004).

go some way towards compensating them for the adverse distributional effects expected from their full participation in the EU's Single Market as well as, eventually, the European Monetary Union. This would increase the voluntariness with which they adopt the terms of accession and eventually improve the legitimacy of the EU in the eyes of their citizens after accession. On the other hand, the unavailability of a viable exit option on the part of the prospective members when negotiating the terms of accession works against their perceived legitimacy of membership. This negative effect may be mitigated by the perception that EU membership represents the most favorable terms of exchange available.

The perceived legitimacy of accession on the part of the citizens of new members countries would be enhanced to the extent that membership is linked to a favorable movement in prices (for example, an increase in real wages, a fall in retail prices and a fall in interest rates) and to the extent that it is seen to improve one's relative income position in the labor force. At the macroeconomic level, legitimacy would be enhanced to the extent that membership is associated with a sustained period of economic growth. Legitimacy would be negatively affected by the adverse evolution of these variables.

The legitimacy of the EU membership for the citizens of new member states would be adversely affected insofar as the transition to accession is linked to unfair privatization processes in their countries. On the other hand, legitimacy would be enhanced to the extent that EU institutions can limit the emergence of distortions to fair competition by private and public agents or, in other words, to the extent that they can consolidate the emergence of a level playing field across these countries. By doing so, they may also give additional breathing space in the face of growing or persisting income inequalities due to such policy reforms. 
Paper published in the Journal of Public Finance and Public Choice 23(3): 183-195 (2004).

The desire to "return to Europe" and the accompanying expectation that it will consolidate democratic systems may legitimize the membership aspirations of potential member countries in the eyes of the political elites in current member states but it may also legitimate the corresponding economic upheaval that membership entails. One would expect this source of legitimacy to fall after membership and especially as democracy becomes entrenched in the new members. On the other hand, to the extent that a shared European identity can emerge over time this would increase the legitimacy of greater economic integration in a wider Europe.

\section{REFERENCES}

Amato, G. - Batт. J., 1999, Final Report of the Reflection Group on the Long-Term Implications of EU Enlargement: The Nature of the New Border, RSC for Advanced Studies and EC Forward Studies Unit, Florence, European University Institute.

Baldwin, R. - Francois, J. - Porters, R., 1997, «EU Enlargement. Small Costs for the West, Big Plans for the East», Economic Policy, 24, pp.127-176.

Bofinger, P., 1995, «The Political Economy of the Eastern Enlargement of the EU», CEPR Discussion Paper, 1234.

Brennan, G. - Buchanan, J., 1985, The Reason of Rules. Constitutional Political Economy, Cambridge University Press. 
Paper published in the Journal of Public Finance and Public Choice 23(3): 183-195 (2004).

Buchanan, J., 1977, Freedom in Constitutional Contract, College Station and London: Texas A\&M University Press.

Buchanan, J. - Tullock, G., 1962, The Calculus of Consent. Logical Foundations of Constitutional Democracy, University of Michigan Press.

COMMISSARIAT GÉNÉRAL DU Plan, 1999, L'Elargissemen de l'Union Européenne à l'Est de l'Europe: des Gains à Descompter à l'Est et à l'Ouest, La Documentation Francaise.

Duch, R., 1993, «Tolerating Economic Reform: Popular Support for Transition to a Free Market in the Former Soviet Union», American Political Science Review, 87(3), pp. 590-607.

ECONOMIST, THE., 2001, «A Survey of European Union Enlargement: Europe's Magnetic Attraction», May.

FAINI, R. - PORTES, R. (eds), 1995, European Union Trade with Eastern Europe: Adjustments and Opportunities, London, CEPR.

FIDRMUC, J., 1999, «The Political Economy of Restructuring of East-West Trade: Economic Winners and Losers in the CEECs and EU», EUI Working Papers RSC, $99(15)$.

FowleR, F., 2001, «Enlargement of the European Union: Impacts on the EU, the Candidates and the Next Neighbors», ECSA Review, 14(1), pp. 2-7.

GrabBe, H. - Hughes, K., 1998, Enlarging the EU Eastwards, London, The Royal Institute of International Affairs.

Handley, D., 1981, «Public Opinion and European Integration: The Crisis of the 1970s», European Journal of Political Research, 9, pp. 335-64. 
Paper published in the Journal of Public Finance and Public Choice 23(3): 183-195 (2004).

Hansen, L. - Williams, M., 1999, «The Myths of Europe: Legitimacy, Community and the 'Crisis' of the EU», Journal of Common Market Studies, 37(2).

Hirschman, A., 1973, «The Changing Tolerance for Income Inequality in the Course of Economic Development», Quarterly Journal of Economics, 87, pp. 544-65.

Howe, P., 1995, «A Community of Europeans: The Requisite Underpinnings», Journal of Common Market Studies, 33(1), pp. 27-46.

InOtAI, A., 2000, «Reflections About the Eastern Enlargement of the European Union», www.epi-bg.org/_en_/discpap_07.htm,.

InTERnational MONETARy Fund, 2000, «Accession of Transition Economies to the European Union: Prospects and Pressures», World Economic Outlook, pp. 138-174.

Kolankiewicz, G., 1993, «The Other Europe: Different Roads to Modernity in Eastern and Central Europe», in GARCIA, S. (ed.), European Identity and the Search for Legitimacy, London and New York, Pinter Publishers.

KornaI, J., 1990, The Road to a Free Economy - Shifting from a Socialist System: The Example of Hungary, New York, Norton.

LAffan, B., 1996, «The Politics of Identity and Political Order in Europe», Journal of Common Market Studies, 34(1), pp. 81-102.

LIPSET, S. M., 1959, «Some Social Requisites of Democracy: Economic Development and Political Legitimacy», American Political Science Review, 53, pp. 69-105.

LIPSET, S. M., 1994, «The Social Requisites of Democracy Revisited», American Sociological Review, 59, pp. 1-22. 
Paper published in the Journal of Public Finance and Public Choice 23(3): 183-195 (2004).

LowenberG, A. - YU, B., 1992, «Efficient Constitutional Formation and Maintenance. The Role of "Exit"», Constitutional Political Economy, 3(1), pp. 51-72.

MoravcsiK, A., 1993, «Preferences and Power in the European Community: A Liberal Intergovernmentalist Approach», Journal of Common Market Studies, 11(4), pp. 473-524.

Mueller, D., 1991, «Constitutional Rights», Journal of Law, Economics, and Organization, 7(2), pp. 313-333.

Neven, D., 1995, «Trade Liberalization with Eastern Nations: Some Distributional Issues», European Economic Review, 39, pp. 622-32.

NorTH, D., 1981, Structure and Change in Economic History, New York, London, W. W. Norton and Company.

NorTH, D., 1990, Institutions, Institutional Change and Economic Performance, Cambridge, Cambridge University Press.

NoRTH, D., 2000, «Big-Bang Transformations of Economic Systems: An Introductory Note», Journal of Institutional \& Theoretical Economics, 156 (1), pp. 3-8.

OBRAdovic, D., 1996, «Policy Legitimacy and the European Union», Journal of Common Market Studies, 34(2), pp. 191-221.

PeJovich, S., 1996, «Law, Tradition and Liberalism in Practice»: Quo Vadis Eastern Europe», Economia delle Scelte Pubbliche, 14(1), pp. 3-13.

PIAZOLO, D., 1999, «The Credibility Effects of EU Institutions for Eastern Europe», Paper Presented at the Annual Meeting of the European Public Choice Society, Lisbon. 
Paper published in the Journal of Public Finance and Public Choice 23(3): 183-195 (2004).

Schimmelfennig, F., 2001, «The Community Trap: Liberal Norms, Rhetorical Action, and the Eastern Enlargement of the European Union», International Organization, $55(1)$.

SMITH, A., «National Identity and the Idea of European Unity», International Affairs 68(1), pp.55-76.

SzCzerbiaK, A., 2001, «Polish Public Opinion: Explaining Declining Support for EU Membership», Journal of Common Market Studies, 39(1), pp. 105-22.

Tsoukalis, L., 2000, «Widening and Deepening - Once Again», www.britishcouncil.org/networkevents/reports/tsoukalis.pdf.

Wallace, H., 1993, «Deepening and Widening: Problems of Legitimacy in the EC», in GARCIA, S. (ed.), European Identity and the Search for Legitimacy, London and New York, Pinter Publishers.

Weber, M., 1946, From Max Weber: Essays in Sociology, New York, Oxford University Press. 